\title{
The Polymorphism and Expression of CYP2E1 Gene and Its Relation to Carcass and Meat Quality of Indonesian Lamb
}

\author{
R. S. Harahap ${ }^{a}$, R. R. Noor ${ }^{b}$, \& A. Gunawan ${ }^{b, *}$ \\ ${ }^{a}$ Graduate School of Animal Production and Technology, Faculty of Animal Science, IPB University \\ bDepartment of Animal Production and Technology, Faculty of Animal Science, IPB University \\ Jalan Agatis, Kampus IPB Darmaga Bogor 16680, Indonesia \\ *Corresponding author: agunawan@apps.ipb.ac.id \\ (Received 08-12-2020; Revised 23-03-2021; Accepted 07-04-2021)
}

\begin{abstract}
The aim of this study was to conduct the genotyping of the single nucleotide polymorphism (SNP) in g.50657948 T>G of the CYP2E1 gene and its relation to the carcass and meat quality. A total of 200 Indonesian lambs consisted of 20 Javanese fat-tail sheep (JFTS), 37 Javanese thin-tail sheep (JTTS), 20 Garut sheep (GS), 21 Jonggol sheep (JS), 34 Garut composite sheep (GCS), 35 compass agrinac sheep (CAS), and 33 Barbados cross sheep (BCS) aged between 10-12 months old were used in this study. The polymorphism of the CYP2E1 gene was characterized using polymerase chain reaction-restriction fragment length polymorphism (PCR-RFLP) with NlaIII enzyme restriction. The CYP2E1 gene found the three genotypes (GG, GT, and TT) and the allele frequencies were in Hardy Weinberg equilibrium. The CYP2E1 gene was significantly associated with meat quality, i.e., $\mathrm{pH}$ value and tenderness, as well as fatty acid composition $(\mathrm{p}<0.05)$, i.e., saturated fatty acid (SFA): caprylic acid (C8:0), arachidic acid (C20:0), heneicosylic acid (C21:0), behenic acid (C:22:0), and tricosylic acid (C23:0), monounsaturated fatty acid (MUFA): elaidic acid (C18:1n9t) and paullinic acid (C20:1); polyunsaturated fatty acid (PUFA): linoleic acid (C18:2n6c) and y-linolenic acid (C20:3n6). A gene expression analysis indicated that the GG genotype had the highest expression level. It could be concluded that the SNP g.50657948 T>G of the CYP2E1 gene could be used for candidate marker-assisted selection to improve the carcass and meat quality of Indonesian lamb.
\end{abstract}

Keywords: CYP2E1 gene; carcass quality; meat quality; lamb

\section{INTRODUCTION}

The meat quality of lamb is very complex, involving many factors such as tenderness, fatty acid composition, odor, and flavor (Shija et al., 2013; Listyarini et al., 2018). Meat tenderness is determined by the amount and solubility of conective tissue, sarcomere, shortening during rigor development, and post-mortem proteolysis of myofibrillar and myofibrillar-associated proteins (Koohmaraie \& Geesink, 2006). On the other hand, intramuscular fat also indirectly influences meat tenderness. The amount of intramuscular fat (IMF) and fatty acid composition play major roles in the quality of meats, including sensory properties, healthy considerations, and flavor compounds (Hocquette et al., 2010; Frank et al., 2016).

The amount of saturated fatty acids (SFA) in the human diet contribute to sudden cardiac arrest (Chiuve et al., 2012). Fatty acid content does not always have a negative impact on meat quality or consumer health. Unsaturated fatty acids have a good effect on health because they are more reactive and as antioxidants in the body. Unsaturated fatty acids are hydrocarbon chains containing at least one carbon-carbon double bond; monounsaturated fatty acids (MUFA) contain one double bond, and polyunsaturated fatty acids (PUFAs) contain many double bonds. The reduction of SFA sources and an increase in the consumption of MUFA and PUFA were associated with cardiovascular protection and reduce atherosclerosis (Blair \& Dhilhon, 2014; Crandell et al., 2016; Ooi et al., 2015). The American Heart Association recommended human diets should include high levels of $n-6$ PUFAs that comprise at least $5 \%-10 \%$ of the energy intake (Harris et al., 2009). Consumption of n-3 PUFAs could reduce the risk of cardiovascular disease (Mori et al., 2014; Merino et al., 2014; Auger et al., 2016), and improves skin microvascular reactivity (Stupin et al., 2018). In addition, both PUFA's play important roles in human health, including brain development (Li et al., 2019), preventing metabolic dysfunction and inflammation (Weir et al., 2018).

Selection programs for the improvement of meat quality based on phenotypic performance is difficult and expensive. However, the used of genetic markers could be combined with the phenotypic selection for improving the meat quality of lamb. From our previous 
study, the CYP2E1 gene showed a significant association with lamb odor and flavor in meat quality of lamb (Harahap et al., 2020). The enzymes activities can be affected by mutations in coding regions of the genes and expressions of mRNA. This idea is supported by various studies involving polymorphisms of family of CYP2E1 gene that has been reported to be related to the levels of androstenone in boar taint (Zadinova et al., 2017), odor and flavor compounds in sheep (Listyarini et al., 2018), and levels of skatole in boar taint (Morlein et al., 2012). Furthermore, Lin et al. (2006) identified a G>A substitution in nucleotide c.1423 in pig which causes the substitution of amino acid alanine (Ala) with threonine (Thr). This mutation was shown to be responsible for a significant decrease in the expression of the CYP2E1 protein and lower catalytic activity for the metabolism of skatole. However, no study related to the investigation of the association and expression of CYP2E1 gene in Indonesian lamb. Therefore, the aim of this study was to identify the association and expression of CYP2E1 genes with meat quality in Indonesian lamb.

\section{MATERIALS AND METHODS}

\section{Animals}

This experimental procedure was approved by the 'Institutional Animal Care and Use Committee (IACUC)" issued by IPB University (approval ID: 1172018 IPB). Association analyses of SNP in the CYP2E1 gene with meat quality of lamb used a total of 200 lambs consisted of 20 Javanese fat-tail sheep (JFTS), 37 Javanese thin-tail sheep (JTTS), 20 Garut sheep (GS), 21 Jonggol sheep (JS), 34 Garut composite sheep (GCS), 35 compass agrinac sheep (CAS), and 33 Barbados cross sheep (BCS). All sheep were maintained in a group caged and were fed ad libitum with fattening feed. The rams were slaughtered in a commercial abattoir at 10-12 months old with an average body weight of $20-25 \mathrm{~kg}$. All rams were slaughtered using the normal commercial procedure as described by Dagong et al. (2012). The whole blood samples were taken for the identification of polymorphisms in CYP2E1 gene and the longissimus dorsi samples were taken for fatty acid analysis, liver tissues for gene expression, and bicep femoris for lamb quality. The samples were put in an ice flask and were stored at a temperature of $-20^{\circ} \mathrm{C}$.

\section{Carcass and Meat Quality Measurements}

The carcass traits measured were live weight, weight of hot carcass, carcass length, and percentage of carcass. Meat quality variables were analyzed, including $\mathrm{pH}$, cooking loss (CL), tenderness, and water holding capacity (WHC). The meat quality measurements refer to the method used by Dagong et al. (2012). The pH was measured 24 hours post mortem using $\mathrm{pH}$ meter, while cooking loss and tenderness were analyzed using bicep femoris sample according to the fiber orientation. The samples were boiled in a waterbath at $80^{\circ} \mathrm{C}$ for approximately $20 \mathrm{~min}$. Brickshaped cuts, each at the size of 2.5 $\times 2.5 \times 3.0 \mathrm{~cm}$, were made to measure tenderness using the Warner Bratzler Shear Force (WBSF) by measuring the amount of strength $\left(\mathrm{kg} / \mathrm{cm}^{2}\right)$ needed to cut the meat cores. Cooking loss measurements (in \%) were calculated as the differences in weights of the samples before and after cooking. The water holding capacity of meat was determined by the filter paper press method. A total of $200 \mathrm{mg}$ meat of lamb were put on the Whatman paper and then placed between two slides where a weight of $100 \mathrm{~g}$ was placed on the top slide for $5 \mathrm{~min}$ to exert downward force and release water from the meat. The water released from the meat was wetting the paper, and the boundary of that wetted area was marked using a sharp pencil and was measured and reported in a percentage ratio of the diameter of the meat to the diameter of the water wetted paper.

\section{Fatty Acid Analysis}

The loin samples were used for fatty acid (FA) analyses. The FA composition was quantified using gas chromatography GC-2010 Plus-Shimadzu according to AOAC 2005. GC-MS-based analytical methods for fatty acid analysis consisted of three steps: (1) extraction of the fatty acids from the sample matrix. Total lipids in each sample were extracted using chloroform-methanol at a ratio of $2: 1(\mathrm{v} / \mathrm{v})$; (2) derivatization of the fatty acid using BF3-methanol to be the fatty acid methyl esters (FAMEs); and (3) GC-MS analysis for FAMEs. The fatness traits were expressed as a proportion of the total FAs included fat content, saturated fatty acid (SFA), monounsaturated fatty acid (MUFA), and polyunsaturated fatty acid (PUFA).

\section{Genomic DNA Extraction, PCR Amplification, and PCR-RFLP}

Genomic DNA was isolated from whole blood samples using a Genomic DNA Mini Kit (Geneaid Biotech, Taiwan). A pair of primers (F:5'-CCCAGTCATCAGAGTCAGTA $-3^{\prime}$ and R: $3^{\prime}$ -GCATACAGTGGTTTTCCTGG- 5') were designed by using MEGA 7 Software and used to amplify the CYP2E1 gene based on the ovine genome sequence (NCBI accession NC_019479.2). The SNP g. 50657948 T>G of CYP2E1 used in this study refers to Harahap et al. (2020). The final 401-bp amplicon was added in $15 \mu \mathrm{L}$ PCR mixture containing $1 \mu \mathrm{L}$ of DNA samples, $0.4 \mu \mathrm{L}$ of primers, $6.1 \mu \mathrm{L}$ of MyTaq HS Red Mix, and $7.5 \mu \mathrm{L}$ of nuclease water. The PCR amplification using AB System machine with five processes consisted of predenaturation for 1 min at $95^{\circ} \mathrm{C}$, followed by 35 cycles of denaturation for $15 \mathrm{~s}$ at $95{ }^{\circ} \mathrm{C}$, annealing for $15 \mathrm{~s}$ at $60{ }^{\circ} \mathrm{C}$, and extension for $10 \mathrm{~s}$ at $72{ }^{\circ} \mathrm{C}$, and a final extension for $1 \mathrm{~min}$ at 72 ${ }^{\circ} \mathrm{C}$. The PCR products were detected by $1.5 \%$ agarose gel electrophoresis. Therefore, the CYP2E1 gene was genotyped using NlaIII enzymes by PCR-RFLP for $4 \mathrm{~h}$ at $37^{\circ} \mathrm{C}$. The digested product was separated using $2 \%$ agarose gel. The fragments were visualized under UV Transilluminator (Alpha Imager, Alpha Innotech, Santa Clara, USA). The PCR-RFLP product consisted of TT: 138 bp, 263 bp, GG: 401 bp, and GT: 138 bp, 263 bp, and $401 \mathrm{bp}$. 


\section{RNA Extraction and Reverse Transcriptase PCR}

The liver tissue was used for RNA extraction. The collected tissue was extracted using the Rneasy Mini Kit (Qiagen) reagent based on the manufacturing protocol. Reverse transcriptase PCR was performed by transcribing RNA extract into complementary DNA (cDNA) using a First Strand cDNA (Thermo Scientific, Lithuanian, EU) Trancriptor Synthesis kit.

\section{Expression Analysis by Quantitative Real Time PCR (qRT-PCR)}

Since the association study showed significantly with lamb tenderness, we measured mRNA expression of CYP2E1 using qRT-PCR. The primers were designed based on the sequences of ovine CYP2E1, GAPDH, and $\beta$-actin (Table 1). qRT-PCR was performed using the SYBR Green Premix. The reaction volume was $10 \mu \mathrm{L}$, including $5 \mu \mathrm{L}$ of SYBR Green Premix, $0.5 \mu \mathrm{L}$ each of forward and reverse primers, $2 \mu \mathrm{L}$ of cDNA, and $2 \mu \mathrm{L}$ of $\mathrm{RNase}$-free $\mathrm{ddH}_{2} \mathrm{O}$. The reaction procedure was as follows: predenaturation at $95{ }^{\circ} \mathrm{C}$ for $30 \mathrm{~s}$, PCR (analysis mode: quantitative) at $95{ }^{\circ} \mathrm{C}$ for $5 \mathrm{~s}$ and at $60{ }^{\circ} \mathrm{C}$ for 30 $\mathrm{s}$ as much 35 cycles, melting (analysis mode: melting curve) at $95{ }^{\circ} \mathrm{C}$ for $5 \mathrm{~s}$, at $60{ }^{\circ} \mathrm{C}$ for $1 \mathrm{~min}$, and cooling at $50{ }^{\circ} \mathrm{C}$ for $30 \mathrm{~s}$. Fold change value were analyzed by calculating the difference between the cycle threshold (CT) value of target and the CT value of reference CT from each sample. The means of fold change value per genotype were analyzed by using Minitab® 18 Software.

\section{Statistical Analysis}

Analysis for allele and genotype frequencies. The allele, genotype frequencies, and Hardy-Weinberg equilibrium status in all sheep populations (JFTS, JTTS, GS, JS, GCS, CAS, and BCS) were calculated by the following formula:

Allele and genotype frequencies (Nei \& Kumar 2000):

Xii= nii / N Xi $=\left(2 n i i+\sum n i j\right) / 2 N$

where Xii was the frequency of ii genotype (GG, GT, and TT); Xi was the frequency of $\mathrm{i}$ allele ( $\mathrm{G}$ and $\mathrm{T})$; nii was the number of the sample of ii genotype; nij was the number of the sample of ij genotype, and $\mathrm{N}$ was the population size.

Hardy Weinberg Equlibrium (HWE) (Hartl \& Clark, 1997):

$\mathrm{x}^{2}=\sum[(\mathrm{O}-\mathrm{E}) 2 / \mathrm{E}]$ where: $\chi 2=$ chi-square; $\mathrm{O}=$ total of observations genotype to-I; E= total of genotype to expectations to-i.

Analysis for carcass, meat quality, and fatty acid. The association between the SNP of the CYP2E1 gene with the carcass and meat quality and fatty acid was performed using T-test procedures to compare genotypes (Minitab® 18 Software). The model of mathematics was:

$$
t=\frac{\left(X_{1}-X_{2}\right)}{\delta^{2} \frac{\sqrt{1}}{n_{1}}+\delta^{2} \frac{\sqrt{1}}{n_{2}}} \delta^{2}
$$

where $\mathrm{X} 1$ and $\mathrm{X} 2$ were the average traits for genotype 1 and $2 ; n 1$ and $n 2$ were an individual number of genotype 1 and 2; and was the combined standard deviation.

Analysis for gene expression related to lamb quality. The relative expression levels of CYP2E1 mRNA were calculated by the difference between the target gene and geometric mean of the references gene $(\Delta C \mathrm{C})$, according to the following formula (Silver et al., 2006):

$\Delta \mathrm{CT}=\mathrm{Ct}_{\text {target gene }}-\mathrm{Ct}_{\text {reference gene }}$.

\section{RESULTS}

\section{Polymorphisms of CYP2E1 Gene in Indonesian Lamb}

The SNP of CYP2E1 gene in g. $50657948 \mathrm{~T}>\mathrm{G}$ was polymorphic in Indonesian lamb (Figure 1). Based on analysis of genotype and allele frequencies (Table 2), we found that three genotypes in CYP2E1 consisted of the GG (401 bp), GT (401, 263, and $138 \mathrm{bp})$, and TT $(263,138 \mathrm{bp})$. The GT genotype was the most frequent (53\%) followed by TT (30\%) and GG (17\%). The G allele frequency was 0.44 and the $\mathrm{T}$ allele frequency was 0.56 . The allele frequencies of the CYP2E1 gene in all sheep populations were in Hardy-Weinberg equilibrium $(p>0.05)$.

\section{Phenotypic of Carcass and Meat Quality of Lamb and Fatty Acid Composition}

Carcass and meat qualities of lamb were detected from six breeds of sheep consisted JTTS, GCS, CAS, $\mathrm{BCS}$, JS, and GS, while fatty acid composition of loin muscle from JFTS, JTTS, GCS, CAS, BCS, and JS (Table 3 \& Table 4). The data of meat quality were live weight, hot carcass weight, carcass length, carcass percentage, $\mathrm{pH}$ value, tenderness, cooking loss, and drip loss from eighty samples of sheep. Fatty acid composition from

Table 1. Primers sequences for quantitative-real time PCR (qRT-PCR)

\begin{tabular}{ccc}
\hline Gene & \multicolumn{1}{c}{ Primer sequence } & Size $(\mathrm{bp})$ \\
\hline CYP2E1 $\left({ }^{\circ} \mathrm{C}\right)$ & 180 \\
& F: 5' - ATT CCC AAG TCC TTC ACC AG -3' & \\
RAPDH & F' - GTT GTT TTT GTG CAC CTG GA -3' & 203 \\
& R: 5' - GAG AAA CCT GCC AAG TAT GA -3' & \\
3-Actin & F: 5' - GAA AAC GAG ATG AGA TTG GC-3' & \\
& R: 5' - CCA TCA TAG AGT GGA GTT CG-3' & \\
\end{tabular}




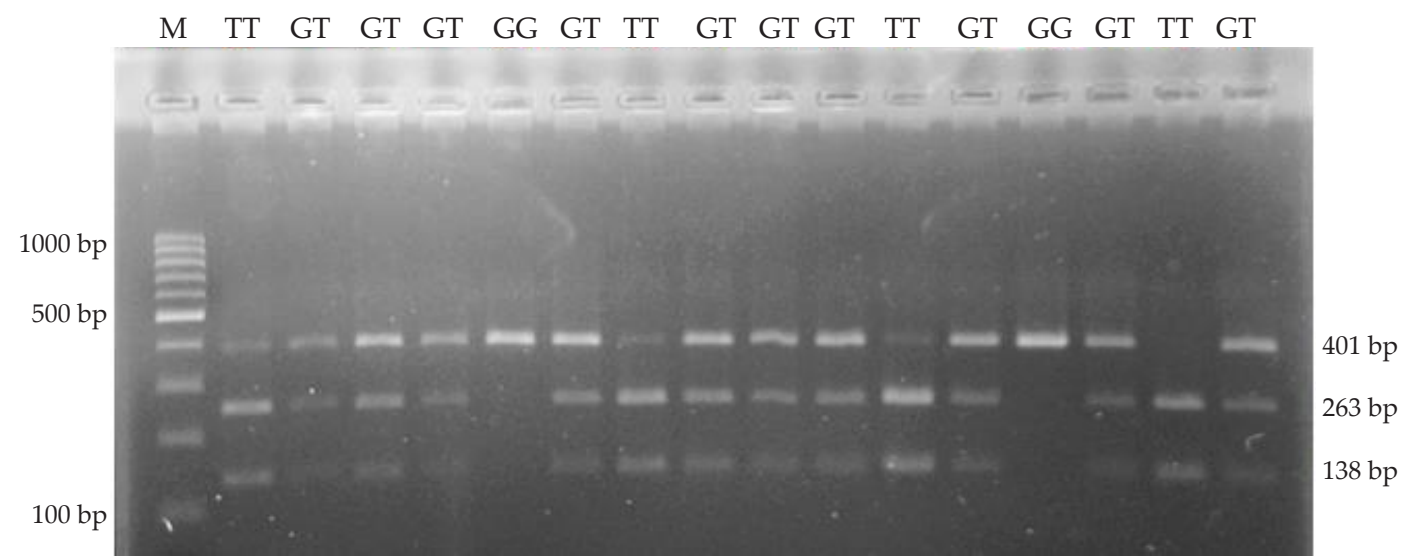

Figure 1. PCR-RFLP genotyping result for the CYP2E1 gene using NlaIII enzyme restriction in 2.5\% agarose; $\mathrm{M}=100$ bp ladder size; GG, GT, and TT= genotypes.

Table 2. The number of animals per genotype and allele frequencies and $\chi 2=$ Chi-square test result

\begin{tabular}{|c|c|c|c|c|c|c|c|}
\hline \multirow{2}{*}{ Sample } & \multirow{2}{*}{$\mathrm{N}$} & \multicolumn{3}{|c|}{ Genotype frequency } & \multicolumn{2}{|c|}{ Allele frequency } & \multirow{2}{*}{$\chi^{2}$} \\
\hline & & GG & GT & TT & G & $\mathrm{T}$ & \\
\hline JFT & 20 & $0.15(3)$ & $0.40(8)$ & $0.45(9)$ & 0.35 & 0.65 & 0.29 \\
\hline JTT & 37 & $0.11(4)$ & $0.35(13)$ & $0.54(20)$ & 0.28 & 0.72 & 0.68 \\
\hline GS & 20 & $0.05(1)$ & $0.40(8)$ & $0.55(11)$ & 0.25 & 0.75 & 0.08 \\
\hline JS & 21 & $0.24(5)$ & $0.57(12)$ & $0.19(4)$ & 0.52 & 0.48 & 0.44 \\
\hline GCS & 34 & $0.21(7)$ & $0.71(24)$ & $0.08(3)$ & 0.56 & 0.44 & 6.33 \\
\hline CAS & 35 & $0.17(6)$ & $0.63(22)$ & $0.20(7)$ & 0.49 & 0.51 & 2.33 \\
\hline BCS & 33 & $0.24(8)$ & $0.61(20)$ & $0.15(5)$ & 0.54 & 0.45 & 1.63 \\
\hline Totals & 200 & $0.17(34)$ & $0.53(107)$ & $0.30(59)$ & 0.44 & 0.56 & 1.52 \\
\hline
\end{tabular}

Note: JFT= Javanese fat-tail sheep; JTT= Javanese thin-tail sheep; GCS= Garut composite sheep; CAS= compass agrinac sheep; BCS= Barbados cross sheep; JS= Jonggol sheep; GS= Garut sheep $\mathrm{n}=$ Number of samples, $\chi 2=$ Chi-square, $\chi_{\mathrm{tab}^{\prime}} 0.05=3.841\left(\chi 2<\chi_{\mathrm{tab}}\right)=\operatorname{significant}$.

Table 3. Phenotypic of carcass and meat quality of Indonesian lamb

\begin{tabular}{|c|c|c|c|c|c|c|}
\hline \multirow{2}{*}{$\begin{array}{l}\text { Carcass and meat } \\
\text { quality traits }\end{array}$} & \multicolumn{6}{|c|}{ Breed $(\mu \pm$ SE Mean $)$} \\
\hline & JTTS (n=15) & GCS $(n=10)$ & CAS $(n=10)$ & $\mathrm{BCS}(\mathrm{n}=10)$ & JS $(n=15)$ & GS $(n=20)$ \\
\hline Live weight (kg) & $25.91 \pm 0.75$ & $27.44 \pm 0.34$ & $21.00 \pm 1.56$ & $15.84 \pm 0.87$ & $23.04 \pm 0.41$ & $24.91 \pm 0.99$ \\
\hline Hot carcass weight $(\mathrm{kg})$ & $10.32 \pm 0.50$ & $9.78 \pm 0.21$ & $7.16 \pm 0.53$ & $5.25 \pm 0.32$ & $8.41 \pm 0.20$ & $6.56 \pm 0.37$ \\
\hline Carcass length $(\mathrm{cm})$ & $70.33 \pm 0.82$ & $74.50 \pm 0.96$ & $106.30 \pm 3.48$ & $100.10 \pm 3.02$ & $64.86 \pm 0.97$ & $64.60 \pm 0.26$ \\
\hline Carcass percentage $(\%)$ & $43.10 \pm 0.91$ & $35.65 \pm 0.66$ & $34.22 \pm 0.94$ & $33.07 \pm 0.61$ & $39.85 \pm 0.43$ & $26.10 \pm 0.77$ \\
\hline $\mathrm{pH}$ value & $6.03 \pm 0.05$ & $6.03 \pm 0.05$ & $6.24 \pm 0.11$ & $6.39 \pm 0.09$ & $5.70 \pm 0.03$ & $7.30 \pm 0.04$ \\
\hline Tenderness $\left(\mathrm{kg} / \mathrm{cm}^{2}\right)$ & $3.92 \pm 0.19$ & $3.92 \pm 0.29$ & $2.81 \pm 0.19$ & $4.55 \pm 0.31$ & $4.11 \pm 0.07$ & $2.86 \pm 0.15$ \\
\hline Cooking loss (\%) & $47.23 \pm 1.52$ & $48.65 \pm 1.48$ & $38.14 \pm 2.75$ & $48.61 \pm 2.20$ & $50.58 \pm 0.81$ & $50.52 \pm 1.06$ \\
\hline Drip loss (\%) & $27.62 \pm 0.48$ & $26.45 \pm 0.79$ & $25.98 \pm 1.49$ & $28.06 \pm 1.29$ & $25.82 \pm 0.44$ & $28.05 \pm 0.32$ \\
\hline
\end{tabular}

Note: JTTS= Javanese thin-tail sheep; GCS= Garut composite sheep; CAS= compass agrinac sheep; BCS= Barbados cross sheep; JS= Jonggol sheep; GS= Garut sheep; $\mu=$ means of carcass and meat quality values; $\mathrm{SE}=$ standard eror.

110 samples of sheep were grouping into saturated fatty acid (SFA), monounsaturated fatty acid (MUFA), and polyunsaturated fatty acid (PUFA).

\section{CYP2E1 Gene Affecting Carcass and Meat Quality}

The association analysis of CYP2E1 gene polymorphisms with carcass characteristics and meat quality were presented in Table 5. The CYP2E1 gene was significantly associated $(\mathrm{p}<0.05)$ with meat quality, i.e., $\mathrm{pH}$ value and lamb tenderness. In general, the T-test showed that the lambs with homozygous GG genotype were associated with a lower $\mathrm{pH}$ value and lamb tenderness than GT and TT genotypes.

\section{CYP2E1 Gene Affecting Fatty Acid Composition}

The parameters of fatty acid (FA) compositions were associated $(p<0.05)$ with CYP2E1 gene polymorphisms consisted of saturated fatty acid (SFA): caprylic acid (C8:0), arachidic acid (C20:0), heneicosylic acid (C21:0), behenic acid (C:22:0), and tricosylic acid (C23:0), monounsaturated fatty acid (MUFA): elaidic acid (C18:1n9t) and paullinic acid (C20:1); polyun- 
Table 4. Phenotypic of the fatty acid composition of Indonesian lamb

\begin{tabular}{|c|c|c|c|c|c|c|}
\hline \multirow{2}{*}{ Fatty acid } & \multicolumn{6}{|c|}{ Breed $(\mu \pm$ SE Mean $)$} \\
\hline & JFTS $(n=20)$ & JTTS (n=33) & GCS $(n=10)$ & CAS $(n=10)$ & $\operatorname{BCS}(n=10)$ & JS $(n=17)$ \\
\hline Fat content $(\%)$ & $7.08 \pm 0.89$ & $3.98 \pm 0.52$ & $1.95 \pm 0.28$ & $1.85 \pm 0.38$ & $1.68 \pm 0.59$ & $2.24 \pm 0.25$ \\
\hline Saturated fatty acid (\%) & $35.28 \pm 1.49$ & $41.43 \pm 1.04$ & $41.78 \pm 1.75$ & $47.85 \pm 1.95$ & $33.30 \pm 2.99$ & $39.46 \pm 3.53$ \\
\hline Caprylic acid, C8:0 & $0.00 \pm 0.00$ & $3.26 \pm 2.58$ & $0.01 \pm 0.01$ & $0.00 \pm 0.00$ & $0.00 \pm 0.00$ & $0.23 \pm 0.04$ \\
\hline Capric acid, C10:0 & $0.00 \pm 0.00$ & $0.48 \pm 0.42$ & $0.00 \pm 0.00$ & $0.00 \pm 0.00$ & $0.00 \pm 0.00$ & $0.22 \pm 0.04$ \\
\hline Lauric acid, C12:0 & $0.10 \pm 0.01$ & $0.27 \pm 0.04$ & $0.05 \pm 0.00$ & $0.04 \pm 0.01$ & $0.02 \pm 0.00$ & $0.10 \pm 0.01$ \\
\hline Tridecylic acid, C13:0 & $0.68 \pm 0.20$ & $0.16 \pm 0.03$ & $0.35 \pm 0.03$ & $0.54 \pm 0.06$ & $0.47 \pm 0.12$ & $0.46 \pm 0.08$ \\
\hline Myristic acid, C14:0 & $0.02 \pm 0.00$ & $1.37 \pm 0.28$ & $0.01 \pm 0.00$ & $0.02 \pm 0.00$ & $0.00 \pm 0.00$ & $0.01 \pm 0.00$ \\
\hline Pentadecylic acid, C15:0 & $0.16 \pm 0.02$ & $0.36 \pm 0.04$ & $0.07 \pm 0.00$ & $0.12 \pm 0.02$ & $0.27 \pm 0.07$ & $0.13 \pm 0.01$ \\
\hline Palmitic acid, C16:0 & $0.45 \pm 0.04$ & $9.79 \pm 1.80$ & $0.49 \pm 0.03$ & $0.51 \pm 0.03$ & $0.38 \pm 0.05$ & $0.49 \pm 0.05$ \\
\hline Margaric acid, C17:0 & $1.90 \pm 0.05$ & $1.28 \pm 0.08$ & $1.17 \pm 0.06$ & $1.25 \pm 0.08$ & $0.98 \pm 0.06$ & $1.51 \pm 0.14$ \\
\hline Stearic acid, C18:0 & $0.76 \pm 0.07$ & $8.43 \pm 1.59$ & $0.28 \pm 0.01$ & $0.39 \pm 0.04$ & $0.52 \pm 0.06$ & $0.00 \pm 0.00$ \\
\hline Arachidic acid, C20:0 & $2.26 \pm 0.20$ & $1.05 \pm 0.17$ & $3.05 \pm 0.22$ & $0.25 \pm 0.01$ & $5.58 \pm 1.21$ & $2.11 \pm 0.25$ \\
\hline Heneicosylic acid, C21:0 & $0.01 \pm 0.00$ & $0.02 \pm 0.01$ & $0.02 \pm 0.00$ & $0.03 \pm 0.00$ & $0.05 \pm 0.00$ & $0.02 \pm 0.00$ \\
\hline Behenic acid, C22:0 & $0.01 \pm 0.00$ & $0.02 \pm 0.00$ & $0.06 \pm 0.00$ & $0.13 \pm 0.02$ & $0.26 \pm 0.03$ & $0.02 \pm 0.00$ \\
\hline Tricosylic acid, C23:0 & $0.00 \pm 0.00$ & $0.00 \pm 0.00$ & $0.03 \pm 0.01$ & $0.07 \pm 0.01$ & $0.15 \pm 0.01$ & $0.01 \pm 0.00$ \\
\hline Lignoceric acid, C24:0 & $0.00 \pm 0.00$ & $0.00 \pm 0.00$ & $0.03 \pm 0.01$ & $0.11 \pm 0.02$ & $0.28 \pm 0.04$ & $0.01 \pm 0.00$ \\
\hline Unsaturated fatty acid (\%) & $35.89 \pm 0.64$ & $34.40 \pm 0.54$ & $27.24 \pm 0.59$ & $8.14 \pm 1.10$ & $31.36 \pm 3.22$ & $31.71 \pm 2.95$ \\
\hline Monounsaturated fatty acid (\%) & $32.95 \pm 0.71$ & $31.17 \pm 0.50$ & $22.73 \pm 0.90$ & $5.08 \pm 0.51$ & $20.94 \pm 2.17$ & $28.38 \pm 2.64$ \\
\hline Myristoleic acid, C14:1 & $3.55 \pm 0.59$ & $2.05 \pm 0.38$ & $2.14 \pm 0.12$ & $3.32 \pm 0.34$ & $1.97 \pm 0.40$ & $2.86 \pm 0.31$ \\
\hline Palmitoleic acid, C16:1 & $18.73 \pm 0.59$ & $11.61 \pm 1.61$ & $16.26 \pm 0.75$ & $18.36 \pm 0.95$ & $13.15 \pm 1.92$ & $18.98 \pm 1.71$ \\
\hline Ginkgoleic acid, C17:1 & $1.21 \pm 0.10$ & $0.61 \pm 0.09$ & $0.80 \pm 0.02$ & $0.80 \pm 0.03$ & $0.60 \pm 0.06$ & $0.68 \pm 0.06$ \\
\hline Oleic acid, C18:1n9c & $0.06 \pm 0.01$ & $13.83 \pm 2.65$ & $0.00 \pm 0.00$ & $23.74 \pm 1.23$ & $0.00 \pm 0.00$ & $0.14 \pm 0.09$ \\
\hline Elaidic acid, C18:1n9t & $10.43 \pm 0.62$ & $8.24 \pm 0.93$ & $21.33 \pm 0.99$ & $23.86 \pm 0.82$ & $15.60 \pm 1.77$ & $15.44 \pm 1.37$ \\
\hline Paullinic acid, C20:1 & $0.00 \pm 0.00$ & $0.00 \pm 0.00$ & $0.00 \pm 0.00$ & $0.00 \pm 0.00$ & $0.24 \pm 0.03$ & $0.00 \pm 0.00$ \\
\hline Nervonic acid, C24:1 & $0.00 \pm 0.00$ & $0.01 \pm 0.00$ & $0.02 \pm 0.01$ & $0.08 \pm 0.01$ & $0.23 \pm 0.05$ & $0.02 \pm 0.00$ \\
\hline Polyunsaturated fatty acid (\%) & $2.94 \pm 0.29$ & $3.22 \pm 0.21$ & $4.51 \pm 0.45$ & $3.06 \pm 0.65$ & $10.42 \pm 1.30$ & $3.33 \pm 0.35$ \\
\hline Linoleic acid, C18:2n6c & $30.11 \pm 0.66$ & $16.50 \pm 2.32$ & $21.18 \pm 0.85$ & $3.22 \pm 0.47$ & $18.94 \pm 2.21$ & $26.70 \pm 2.49$ \\
\hline y-linolenic acid, C18:3n6 & $0.06 \pm 0.00$ & $0.11 \pm 0.09$ & $0.16 \pm 0.01$ & $0.00 \pm 0.00$ & $0.33 \pm 0.02$ & $0.11 \pm 0.01$ \\
\hline$\alpha$-linolenic acid, C18:3n3 & $0.23 \pm 0.02$ & $0.49 \pm 0.05$ & $0.13 \pm 0.00$ & $0.14 \pm 0.01$ & $0.21 \pm 0.04$ & $0.52 \pm 0.05$ \\
\hline Eicosedienoic acid, C20:2 & $0.05 \pm 0.00$ & $0.04 \pm 0.00$ & $0.04 \pm 0.00$ & $0.06 \pm 0.01$ & $0.10 \pm 0.04$ & $0.02 \pm 0.00$ \\
\hline Dihomo-y-linolenic acid, C20:3n6 & $0.02 \pm 0.01$ & $0.02 \pm 0.00$ & $0.08 \pm 0.02$ & $0.17 \pm 0.02$ & $0.31 \pm 0.06$ & $0.03 \pm 0.00$ \\
\hline Arachidonic acid, C20:4n6 & $0.32 \pm 0.05$ & $0.36 \pm 0.04$ & $1.07 \pm 0.19$ & $2.18 \pm 0.54$ & $3.49 \pm 0.59$ & $0.29 \pm 0.02$ \\
\hline Docosadienoic acid, C22:2 & $0.00 \pm 0.00$ & $0.00 \pm 0.00$ & $0.00 \pm 0.00$ & $0.06 \pm 0.03$ & $0.00 \pm 0.00$ & $0.00 \pm 0.00$ \\
\hline Eicosapentaenoic acid, C20:5n3 & $0.02 \pm 0.01$ & $0.28 \pm 0.03$ & $0.07 \pm 0.01$ & $0.15 \pm 0.05$ & $0.47 \pm 0.09$ & $0.28 \pm 0.02$ \\
\hline Cervonic acid, C22:6n3 & $0.01 \pm 0.00$ & $0.05 \pm 0.01$ & $0.05 \pm 0.01$ & $0.03 \pm 0.01$ & $0.15 \pm 0.05$ & $0.03 \pm 0.00$ \\
\hline Total fatty acid (\%) & $71.26 \pm 1.36$ & $77.01 \pm 1.40$ & $69.08 \pm 1.88$ & $79.79 \pm 2.32$ & $64.90 \pm 4.91$ & $71.31 \pm 6.36$ \\
\hline
\end{tabular}

Note: JFTS= Javanese thin-tail sheep; JTTS= Javanese thin-tail sheep; GCS= Garut composite sheep; CAS= compass agrinac sheep; BCS= Barbados cross sheep; JS= Jonggol sheep; $\mu=$ means of carcass and meat quality values; $S E=$ standard eror.

saturated fatty acid (PUFA): linoleic acid (C18:2n6c) and $\mathrm{y}$-linolenic acid (C20:3n6). The associations of CYP2E1 gene with fatty acid compositions are presented in Table 6 . The GG genotype was associated with lower SFA but higher UFA followed by GT and TT genotypes. These results indicated that the CYP2E1 gene might play an important role in lipid metabolism.

\section{Expression of CYP2E1 Gene}

The expression levels of CYP2E1 were differently regulated $(p<0.05)$ among the sheep with a higher effect of GG genotype than the GT and TT genotypes (Figure 2). Quantitative real-time PCR analysis showed the abundance of CYP2E1 transcripts in animals with divergent lamb qualities in the liver. The GG genotype expression had a low total of saturated fatty acid and high totals of unsaturated fatty acid than others genotype, which is indicates that sheep with GG genotype of CYP2E1 will produce a healthy lamb meat cause have a high totals of unsaturated fatty acid (Table 6).

\section{DISCUSSION}

The polymorphisms of CYP2E1 gene in this study had three genotypes in Indonesian lamb. However, Listyarini et al. (2018) found that only two genotypes in Javanese fat-tail sheep, namely GT and TT genotypes. In this study, GT genotype was common, but Listyarini et al. (2018) found that the TT genotype was more frequent 
Table 5. The association analysis of CYP2E1 gene polymorphisms with carcass characteristic and lamb quality

\begin{tabular}{|c|c|c|c|c|c|c|}
\hline \multirow{2}{*}{$\begin{array}{l}\text { Carcass and meat quality } \\
\text { traits }\end{array}$} & \multicolumn{3}{|c|}{ Genotype of CYP2E1 ( $\mu \pm$ Std Dev) } & \multicolumn{3}{|c|}{ p-Value } \\
\hline & GG $(n=17)$ & GT $(n=34)$ & TT $(n=29)$ & GG vs GT & GG vs TT & GT vs TT \\
\hline Live weight $(\mathrm{kg})$ & $22.48 \pm 4.61$ & $22.74 \pm 4.75$ & $24.81 \pm 4.60$ & 0.853 & 0.108 & 0.085 \\
\hline Hot carcass $(\mathrm{kg})$ & $8.04 \pm 1.92$ & $7.57 \pm 1.90$ & $8.27 \pm 2.70$ & 0.417 & 0.741 & 0.252 \\
\hline Carcass length $(\mathrm{cm})$ & $80.00 \pm 18.68$ & $77.62 \pm 19.64$ & $70.28 \pm 13.61$ & 0.676 & 0.072 & 0.087 \\
\hline Carcass percentage (\%) & $36.86 \pm 4.43$ & $34.54 \pm 5.95$ & $34.31 \pm 8.49$ & 0.120 & 0.184 & 0.902 \\
\hline $\mathrm{pH}$ value & $6.10 \pm 0.46^{\mathrm{b}}$ & $6.36 \pm 0.64$ & $6.50 \pm 0.64^{\mathrm{a}}$ & 0.115 & $0.020^{*}$ & 0.382 \\
\hline Tenderness $\left(\mathrm{kg} / \mathrm{cm}^{2}\right)$ & $4.09 \pm 1.02^{\mathrm{a}}$ & $3.66 \pm 0.80$ & $3.32 \pm 0.94^{b}$ & 0.144 & $0.018^{*}$ & 0.143 \\
\hline Cooking loss (\%) & $49.47 \pm 5.37$ & $48.91 \pm 5.82$ & $45.77 \pm 7.99$ & 0.736 & 0.068 & 0.086 \\
\hline Drip loss (\%) & $27.47 \pm 3.21$ & $26.95 \pm 2.78$ & $27.03 \pm 2.56$ & 0.578 & 0.638 & 0.908 \\
\hline
\end{tabular}

Note: $\mu=$ means of carcass and meat quality values; Std Dev= standard deviation; ${ }^{*}=$ significantly at $\mathrm{p}<0.05$; a, b,c= superscript to show a signifanctly different variables. Numbers shown in parentheses are the number of individuals with the specified genotype.

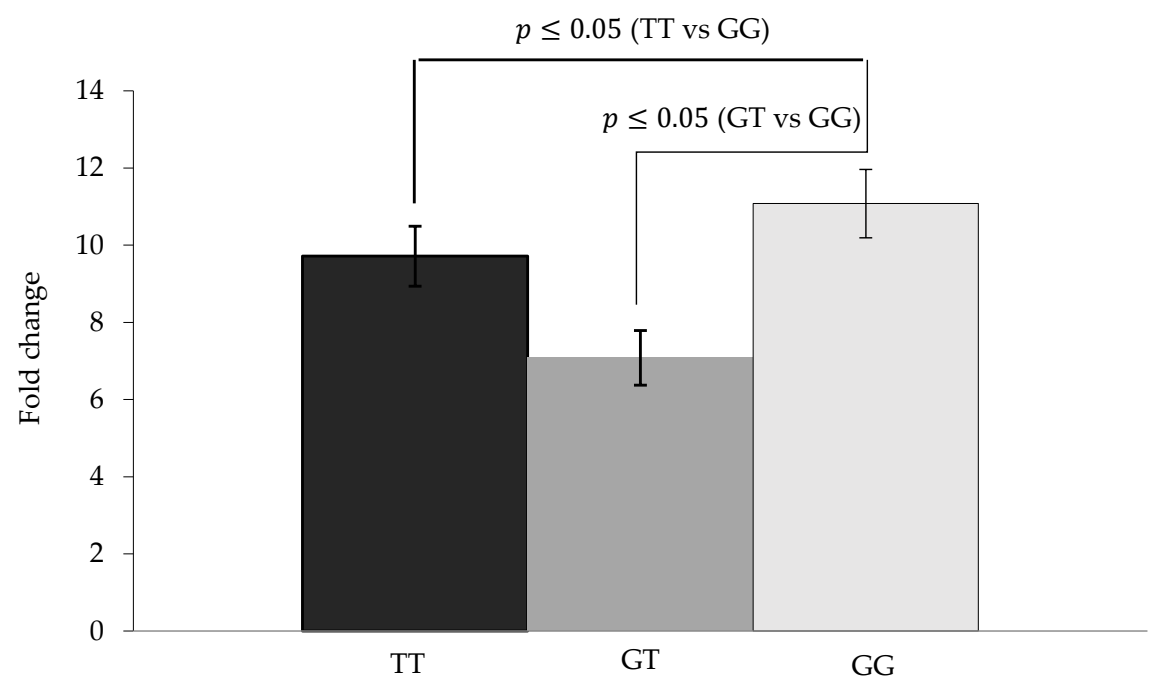

Figure 2. Expression levels of meat quality concerning for CYP2E1 genotype in Indonesian sheep from high meat quality (GG genotype) and low meat quality (GT and TT genotypes).

than GT genotype. The mutation in the genotype of thymine to guanine in the CYP2E1 gene is categorized as a translation mutation. Translation mutation is a mutation in purine bases $(A, G)$ to pyrimidine bases $(C, T)$.

In the association analysis, the SNP of CYP2E1 gene (g.50657948 $\mathrm{T}>\mathrm{G}$ ) was associated with $\mathrm{pH}$ value and lamb tenderness (Table 4). GG genotypes were associated with low $\mathrm{pH}$ value and meat tenderness in Indonesian lamb than GT and TT genotypes. The $\mathrm{pH}$ values found in this study were not categorized in normal $\mathrm{pH}$. The $\mathrm{pH}$ values of a fresh slaughtered sheep's carcass should be around 7.0 to 7.3. The ultimate $\mathrm{pH}$ values vary between 5.5 and 5.8 , which are influenced by several factors, such as gender, slaughter age, production system, genetics, and pre-slaughter management (Zimerman et al., 2011; Gallo et al., 2019). The pH value is related to lamb tenderness. The higher final $\mathrm{pH}$ could produce a dark firm dry (DFD) meat that caused a low tenderness (Santos et al., 2019). Measurement of meat tenderness value was conducted using the Warner Bratzler Shear Force (WBSF) tools. Meat tenderness of CAS and GS in this study were in the range of tenderness reported by Dagong et al. (2012) that the JTT had a $2.62-3.13 \mathrm{~kg} / \mathrm{cm}^{2}$ for WBSF, while JTT, GCS, BCS, and JS in this study had a higher when compared to their study. The results showed that the breed of sheep could influence a variant of meat tenderness. Meat tenderness is determined by the amount and solubility of conective tissue, sarcomere, shortening during rigor development, and post-mortem proteolysis of myofibrillar and myofibrillar-associated proteins (Koohmaraie \& Geesink 2006). Other parameters of meat quality related to CYP2E1 gene polymorphisms were studied by Listyarini et al. (2018), reporting that CYP2E1 gene polymorphisms associated with flavor and odor in Indonesian lamb. The CYP2E1 gene plays an important role in the metabolism of skatole and androstenone (Listyarini et al., 2018; Gunawan et al., 2013a; Gunawan et al., 2013b; Morlein et al., 2012; Neuhoff et al., 2015; Zadinova et al., 2016). The activity of CYP2E1 in the liver significantly influences skatole concentrations in the fat. The skatole levels in the fat of boars increase during puberty and are correlated with the fat androstenone levels (Robic et al., 2008; Wiercinska et al., 2012). Consequently, male pigs were routinely castrated for meat production. The CYP2E1 gene affected levels of skatole on lamb meat (Harahap et al. 2020). Skatole is produced in the intestine by bacterial degradation and absorbed into the blood. If it passes through the liver without being metabolized, it accumulates in adipose tissue, the liver, and the kidneys. The 
Table 6. The association of CYP2E1 gene with fatty acid composition

\begin{tabular}{|c|c|c|c|c|c|c|}
\hline \multirow{2}{*}{ Fatness traits } & \multicolumn{3}{|c|}{ Genotype of CYP2E1 $(\mu \pm$ Std Dev $)$} & \multicolumn{3}{|c|}{ p-Value } \\
\hline & GG $(n=20)$ & GT $(n=43)$ & TT $(n=37)$ & GG vs GT & GG vs TT & GT vs TT \\
\hline Fat content $(\%)$ & $3.32 \pm 3.05$ & $3.26 \pm 2.58$ & $4.32 \pm 3.94$ & 0.937 & 0.297 & 0.169 \\
\hline Saturated fatty acid (\%) & $38.98 \pm 8.64$ & $40.52 \pm 9.32$ & $39.22 \pm 9.49$ & 0.524 & 0.925 & 0.539 \\
\hline Caprylic acid, C8:0 & $0.07 \pm 0.17$ & $0.05 \pm 0.11^{\mathrm{a}}$ & $0.01 \pm 0.05^{\mathrm{b}}$ & 0.647 & 0.129 & $0.031^{*}$ \\
\hline Capric acid, C10:0 & $0.08 \pm 0.05$ & $0.40 \pm 2.12$ & $0.10 \pm 0.00$ & 0.319 & 0.067 & 0.363 \\
\hline Lauric acid, C12:0 & $0.51 \pm 0.49$ & $0.52 \pm 0.57$ & $0.39 \pm 0.33$ & 0.96 & 0.357 & 0.244 \\
\hline Tridecylic acid, C13:0 & $0.01 \pm 0.01$ & $0.01 \pm 0.01$ & $0.01 \pm 0.01$ & 0.577 & 0.449 & 0.098 \\
\hline Myristic acid, C14:0 & $2.72 \pm 1.73$ & $3.08 \pm 1.69$ & $3.19 \pm 1.72$ & 0.442 & 0.333 & 0.778 \\
\hline Pentadecylic acid, C15:0 & $0.48 \pm 0.13$ & $0,49 \pm 0.17$ & $0.54 \pm 0.16$ & 0.748 & 0.131 & 0.199 \\
\hline Palmitic acid, C16:0 & $17.30 \pm 5.09$ & $18.64 \pm 4.54$ & $18.83 \pm 3.98$ & 0.319 & 0.253 & 0.849 \\
\hline Margaric acid, C17:0 & $0.81 \pm 0.29$ & $0.89 \pm 0.34$ & $0.98 \pm 0.35$ & 0.318 & 0.059 & 0.285 \\
\hline Stearic acid, C18:0 & $16.53 \pm 4.26$ & $16.13 \pm 5.74$ & $14.97 \pm 6.11$ & 0.761 & 0.266 & 0.386 \\
\hline Arachidic acid, C20:0 & $0.18 \pm 0.12^{\mathrm{a}}$ & $0.12 \pm 0.09$ & $0.09 \pm 0.06^{\mathrm{b}}$ & 0.065 & $0.016^{*}$ & 0.335 \\
\hline Heneicosylic acid, C21:0 & $0.04 \pm 0.02^{\mathrm{a}}$ & $0.02 \pm 0.02^{b}$ & $0.02 \pm 0.02^{b}$ & $0.019^{*}$ & $0.021^{*}$ & 0.858 \\
\hline Behenic acid, C22:0 & $0.04 \pm 0.17^{\mathrm{a}}$ & $0.06 \pm 0.08$ & $0.04 \pm 0.05^{b}$ & 0.179 & $0.028^{*}$ & 0.064 \\
\hline Tricosylic acid, C23:0 & $0.05 \pm 0.07^{\mathrm{a}}$ & $0.03 \pm 0.05$ & $0.02 \pm 0.03^{b}$ & 0.25 & $0.028^{*}$ & 0.063 \\
\hline Lignoceric acid, C24:0 & $0.09 \pm 0.15$ & $0.05 \pm 0.08$ & $0.02 \pm 0.04$ & 0.286 & 0.058 & 0.071 \\
\hline Unsaturated fatty acid (\%) & $32.45 \pm 5.03$ & $29.83 \pm 11.86$ & $30.59 \pm 10.08$ & 0.262 & 0.413 & 0.759 \\
\hline Monounsaturated fatty acid (\%) & $26.96 \pm 6.80$ & $25.60 \pm 10.90$ & $27.50 \pm 9.96$ & 0.548 & 0.809 & 0.417 \\
\hline Myristoleic acid, C14:1 & $0.14 \pm 0.07$ & $0.15 \pm 0.13$ & $0.13 \pm 0.08$ & 0.530 & 0.882 & 0.419 \\
\hline Palmitoleic acid, C16:1 & $1.42 \pm 0.43$ & $1.51 \pm 0.44$ & $1.64 \pm 0.43$ & 0.416 & 0.071 & 0.211 \\
\hline Ginkgoleic acid, C17:1 & $0.31 \pm 0.32$ & $0.31 \pm 0.31$ & $0.36 \pm 0.40$ & 0.979 & 0.611 & 0.519 \\
\hline Oleic acid, C18:1n9c & $25.01 \pm 6.62$ & $23.58 \pm 10.6$ & $25.35 \pm 9.64$ & 0.518 & 0.875 & 0.437 \\
\hline Elaidic acid, C18:1n9t & $0.31 \pm 0.82^{b}$ & $3.61 \pm 8.43^{\mathrm{a}}$ & $3.51 \pm 7.27^{\mathrm{b}}$ & $0.015^{*}$ & $0.012^{*}$ & 0.955 \\
\hline Paullinic acid, C20:1 & $0.07 \pm 0.14^{\mathrm{a}}$ & $0.03 \pm 0.07$ & $0.01 \pm 0.01^{\mathrm{b}}$ & 0.127 & $0.035^{*}$ & 0.060 \\
\hline Nervonic acid, C24:1 & $0.08 \pm 0.15$ & $0.04 \pm 0.08$ & $0.01 \pm 0.03$ & 0.246 & 0.058 & 0.063 \\
\hline Polyunsaturated fatty acid (\%) & $5.28 \pm 2.81^{\mathrm{a}}$ & $4.23 \pm 3.49$ & $3.08 \pm 1.40^{\mathrm{b}}$ & 0.209 & $0.003^{*}$ & 0.053 \\
\hline Linoleic acid, C18:2n6c & $3.16 \pm 1.24^{\mathrm{a}}$ & $2.46 \pm 2.49$ & $1.82 \pm 0.93^{b}$ & 0.144 & $0.000^{*}$ & 0.127 \\
\hline y-linolenic acid, C18:3n6 & $0.03 \pm 0.07$ & $0.08 \pm 0.14$ & $0.01 \pm 0.04$ & 0.806 & 0.946 & 0.679 \\
\hline$\alpha$-linolenic acid, C18:3n3 & $0.32 \pm 0.28$ & $0.35 \pm 0.25$ & $0.36 \pm 0.30$ & 0.759 & 0.637 & 0.809 \\
\hline Eicosedienoic acid, C20:2 & $0.04 \pm 0.02$ & $0.05 \pm 0.07$ & $0.04 \pm 0.03$ & 0.301 & 0.900 & 0.281 \\
\hline Dihomo-y-linolenic acid, C20:3n6 & $0.10 \pm 0.11^{\mathrm{a}}$ & $0.06 \pm 0.09^{b}$ & $0.04 \pm 0.05^{c}$ & 0.609 & $0.025^{*}$ & $0.050^{*}$ \\
\hline Arachidonic acid, C20:4n6 & $1.32 \pm 1.57$ & $0.99 \pm 1.48$ & $0.59 \pm 0.81$ & 0.451 & 0.065 & 0.125 \\
\hline Docosadienoic acid, C22:2 & $0.00 \pm 0.00$ & $0.01 \pm 0.03$ & $0.01 \pm 0.05$ & nt & nt & 0.945 \\
\hline Eicosapentaenoic acid, C20:5n3 & $0.25 \pm 0.22$ & $0.19 \pm 0.21$ & $0.17 \pm 0.20$ & 0.333 & 0.215 & 0.712 \\
\hline Cervonic acid, C22:6n3 & $0.05 \pm 0.03$ & $0.05 \pm 0.10$ & $0.04 \pm 0.05$ & 0.711 & 0.200 & 0.231 \\
\hline Total fatty acid (\%) & $71.63 \pm 12.09$ & $73.70 \pm 14.12$ & $73.41 \pm 14.17$ & 0.553 & 0.627 & 0.922 \\
\hline
\end{tabular}

Note: $\mathrm{nt}=$ not tested using T-test due to no amount detected; $\mu=$ means of fatty acid composition; Std Dev= standard deviation; ${ }^{*}=$ significantly at $\mathrm{p}<0.05$ $\mathrm{a}, \mathrm{b}, \mathrm{c}=$ superscript to show a signifanctly different variables. Numbers shown in parentheses are the number of individuals with the specified genotype.

high expression of the CYP2E1 gene causes low levels of skatole in the adipose tissue that affects the flavor and odor of meat quality of lamb. The CYP2E1 gene plays a role in metabolism carcinogenesis (Leung et al., 2013). Its effect on carcinogens metabolism was studied not only in humans but also in mice (Konstandi et al., 2013).

The expression of CYP2E1 gene was the highest in GG genotype than GT and TT genotypes (Figure 2). The expression of GG genotypes was associated with low totals of SFA and high totals of UFA (Table 6.), and the high levels of FA caused an undesirable flavour and odor. Two chemical compounds that determine the lamb's odor and flavor consisted of branched-chain fatty acid and skatole (BCFA). The BCFAs consisted of 4-methyloctanoic acid (4-MeO) and 4-methylnonanoic acid (4-MeN), which were dominated by fatty acids stearic and oleic that were esterified in body fats, but released to an extent as free acids on cooking and thus contributing to flavor (Lu et al., 2014; Listyarini et al., 2018).

Overall, the result showed the average value of SFA in lamb meat was higher than UFA (PUFA+MUFA) in all genotypes. This result agrees with the current study by Munyaneza et al. (2019) that generally fatty composition of lamb meat is dominated by SFA. MUFA could reduce LDL cholesterol (low-density lipoprotein) and increase HDL cholesterol (high-density lipoprotein) levels. Oleic acid $(\mathrm{C} 18: \ln 9 \mathrm{c})$ was the dominant fatty acid in total 
MUFA. This result is consistent with the researches by Gunawan et al. $(2018,2019)$, who found that oleic acid is most commonly found in muscle. PUFAs have been identified to have benefits in the physiological system of blood pressure, heart rate, inflammation, and reduce the risk of coronary heart disease.

The CYP2E1 gene in this study was significantly different in mRNA levels (Figure 2). This result is consistent with the study of Kubesova et al. (2019) reported a significant difference in mRNA levels of CYP2E1 in the pig. The expression of the CYP2E1 gene is affected by sex. Female pigs showed higher expression of CYP1A2 and CYP2E1 than the boar (Rasmussen et al., 2011). Ma et al. (2019) reported the expression of the CYP2E1 gene in lipid metabolite with other genes such apolipoprotein C3 (APOC3), cytochrome P4502C34 (CYP2C34), and sulfate transferase 2A1 (SULT2A1) were not influenced by restricted feed intake.

\section{CONCLUSION}

The SNP g.50657948 T>G of CYP2E1 gene was polymorphic in seven breeds of Indonesian lambs. The variant genotypes of CYP2E1 gene was significantly associated with lamb quality, i.e, $\mathrm{pH}$ value, lamb tenderness, and fatty acid composition. The expressions of GG genotypes was higher than GT and TT genotypes. Based on the finding, SNP g.50657948 T>G of the CYP2E1 gene with GG genotype could be used as a candidate marker for selecting sheep with high lamb quality.

\section{CONFLICT OF INTEREST}

Asep Gunawan serves as an editor of the Tropical Animal Science Journal, but has no role in the decision to publish this article. The authors also declare that there is no conflict of interest.

\section{ACKNOWLEDGEMENT}

This work was financially supported by Directorate General of Resources for Science, Technology and Higher Education, Ministry of Research, Technology and Higher Education Contract. Number: 200/SP2H/ PMDSU/DRPM/2020 date 31 ${ }^{\text {st }}$ August 2020.

\section{REFERENCES}

AOAC. 2005. Official Methods of Analysis of AOAC International. 18th ed. Assoc. Off. Anal. Chem., Arlington.

Auger, C., A. Said, P. N. Nguyen, P. Chabert, N. Idris-khodja, \& V. B. Schini-kerth. 2016. Potential of food and natural products to promote endothelial and vascular health. J. Cardiovasc. Pharmacol. 68: 11-18. https://doi.org/10.1097/ FJC.0000000000000382

Blair, H. A. \& S. Dhillon. 2014. Omega-3 carboxylic acids (epanova): A review of its use in patients with severe hypertriglyceridemia. Am. J. Cardiovasc. Drugs. 14: 393-400. https://doi.org/10.1007/s40256-014-0090-3

Crandell, J. R., C. Tartaglia, \& J. Tartaglia. 2016. Lipid effects of switching from prescription epa+dha (omega-3-acid ethyl esters) to prescription epa-only (icosapent ethyl) in dyslipidemic patients. Postgrad. Med. 128: 859-864. https://doi.or g/10.1080/00325481.2016.1241129

Chiuve, S. E., E. B. Rimm, K. R. Sandhu, A. M. Bernstein, K. N. Rexrode, J. E. Manson, W. C. Willett, \& C. M. Albert. 2012. Dietary fat quality and risk of sudden cardiac death in women. Am. J. Clin. Nutr. 96: 498-507. https://doi. org/10.3945/ajcn.112.040287

Dagong, M. I. A., R. Herman, C. Sumantri, R. R. Noor, \& M. Yamin. 2012. Karakteristik karkas dan sifat fisik daging domba ekor tipis (det) berdasarkan variasi genotip gen kalpastatin (cast) (lokus intron 5 - ekson 6). JITV. 17: 13-24.

Frank, D., S. T. Joo, \& R. D. Warner. 2016. Consumer Acceptability of Intramuscular Fat. Korean. J. Food. Sci. Technol. 36: 699708. https://doi.org/10.5851/kosfa.2016.36.6.699

Gallo, S. B., M. B. Arrigoni, A. L. S. Lemos, M. M. H. Haguiwara, \& H. V. A. Bezerra. 2019. Influence of lamb finishing system on animal performance and meat quality. Acta. Sci. Anim. Sci. 41: e44742. https://doi.org/10.4025/ actascianimsci.v41i1.44742

Gunawan, A., R. S. Harahap, K. Listyarini, \& C. Sumantri. 2019. Identification polymorphism of DGAT1 gene and its association with characteristic of carcass and fat traits in sheep. JITRO. 6: 259-266. https://doi.org/10.33772/jitro. v6i2.7141

Gunawan, A., D. Anggrela, K. Listyarini, M. A. Abuzahra, Jakaria, M. Yamin, I. Inounu, \& C. Sumantri. 2018. Identification of single nucleotide polymorphism and pathway analysis of Apolipoprotein A5 (APOA5) related to fatty acid traits in Indonesian sheep. Trop. Anim. Sci. J. 41: 165-173. https://doi.org/10.5398/tasj.2018.41.3.165

Gunawan, A., S. Sahadevan, M. U. Cinar, C. Neuhoff, C. GroßeBrinkhaus, L. Frieden, D. Tesfaye, E. Tholen, C. Looft, D. S. Wondim, \& M. Holker. 2013a. Identification of the novel candidate genes and variants in boar liver tissues with divergent skatole levels using RNA deep sequencing. PLoS One. 8: p.e72298. https://doi.org/10.1371/ journal.pone.0072298

Gunawan, A., S. Sahadevan, C. Neuhooff, C. G. Brinkhaus, A. Gad, L. Frieden, D. Tesfaye, E. Tholen, C. Looft, M. J. Uddin, K. Schellander, \& M. U. Cinar. 2013b. RNA deep sequencing reveals novel candidate genes and polymorphism in boar testis and liver tissues with divergent androstenone levels. PloS One. 8: e63259. https://doi.org/10.1371/ journal.pone.0063259

Harahap, R. S., A. Gunawan, \& R. R. Noor. 2020. Effect of CYP2E1 gene polymorphisms on lamb odor and flavour in Indonesian sheep. The 3th International Conference of Animal Science and Technology (ICAST) 2020; 2020 Nov 3; Makassar, Indonesia. https://doi. org/10.1088/1755-1315/788/1/012022

Harris, W. S., D. Mozaffarian, E. Rimm, P. Kris-Etherton, L. L. Rudel, L. J. Appel, M. M. Engler, M. B. Engler, \& F. Sacks. 2009. Omega-6 fatty acids and risk for cardiovascular disease: A science advisory from the American Heart Association Nutrition Subcommittee of the Council on Nutrition, Physical Activity, and Metabolism; Council on Cardiovascular Nursing; and Council on Epidemiology and Prevention. Circulation. 119: 902-907. https://doi. org/10.1161/CIRCULATIONAHA.108.191627

Hartl, D. L. \& A. G. Clark. 1997. Principle of Population Genetic. Sunderland. Sinauer Associates.

Hocquette, J. F., F. Gondret, E. Baeza, F. Medale, C. Jurie, \& D. W. Pethick. 2010. Intramuscular fat content in meatproducing animals: development, genetic and nutritional control, and identification of putative markers. Anim. 4: 303-19. https://doi.org/10.1017/S1751731109991091

Konstandi, M., J. Cheng, \& F. J. Gonzalez. 2013. Sex steroid hormones regulate constitutive expression of CYP2E1 in female mouse liver. Am. J. Physiol. Endrocrinol. Metab. 304: E1118-E1128. https://doi.org/10.1152/ajpendo.00585.2012 
Koohmaraie, M. \& G. H. Geesink. 2006. Contribution of postmortem muscle biochemistry to the delivery of consistent meat quality with particular focus on the calpain system. Meat Sci. 74: 34-43. https://doi.org/10.1016/j. meatsci.2006.04.025

Kubesova, A., K. Stastny, M. Faldyna, Z. Sladek, I. Steinhauserova, G. Borilova, \& A. Knoll. 2019. mRNA Expression of CYP2E1, CYP2A19, CYP1A2, HSD3B, SULT1A1 and SULT2A1 genes in surgically castrated, immunologically castrated, entire male and female pigs and correlation with androstenone, skatole, indole and Improvac-specific antibody levels. CJAS. 64: 89-97. https:// doi.org/10.17221/159/2018-CJAS

Leung, T., R. Rajendran, S. Singh, R. Garva, M. K. Demonacos, \& C. Demonacos. 2013. Cytochrome P450 2E1 (CYP2E1) regulates the response to oxidative stress and migration of breast cancer cells. BCR. 15: R107. https://doi.org/10.1186/ bcr3574

Li, Q., J. Chen, X. Yu, \& J. M. Gao. 2019. A mini review of nervonic acid: Source, production, and biological functions. Food Chem. 301: 125286. https://doi.org/10.1016/j. foodchem.2019.125286

Lin, Z., Y. Lou, \& E. J. Squires. 2006. Functional polymorphism in porcine CYP2E1 gene: Its association with skatole levels. J. Steroid. Biochem. Mol. Biol. 99: 231-237. https://doi. org/10.1016/j.jsbmb.2005.07.001

Listyarini, K., Jakaria, M. J. Uddin, C. Sumantri, \& A. Gunawan. 2018. Association and expression of CYP2A6 AND KIF12 genes related to lamb flavour and odor. Trop. Anim. Sci. J. 41: 100-107. https://doi.org/10.5398/tasj.2018.41.2.100

Lu, Y., O. A. Young, \& J. D. Brooks. 2014. Physicochemical and sensory characteristics of fermented sheep meat sausage. Food. Sci. Nutr. 2: 669-675. https://doi.org/10.1002/fsn3.151

Ma, X., L. Wang, Z. Shi, W. Chen, X. Yang, Y. Hu, C. Zheng, \& Z. Jiang. 2019. Mechanism of continuous high temperature affecting growth performance, meat quality, and muscle biochemical properties of finishing pigs. Genes Nutr. 14: 23. https://doi.org/10.1186/s12263-019-0643-9

Merino, J., A. Sala-Vila, R. Kones, R. Ferre, N. Plana, J. Girona, D. Ibarretxe, M. Heras, E. Ros, \& L. Masa. 2014. Increasing long-chain n-3PUFA consumption improves small peripheral artery function in patients at intermediate-high cardiovascular risk. J. Nutr. Biochem. 25: 642-646. https://doi. org/10.1016/j.jnutbio.2014.02.004

Mori, T. A. 2014. Omega-3 fatty acids and cardiovascular disease: epidemiology and effects on cardiometabolic risk factors. Food Funct. 5: 2004-2019. https://doi.org/10.1039/ C4FO00393D

Morlein, D., M. Lungershausen, K. Steinke, A. R. Sharifi, \& C. Knorr. 2012. A single nucleotide polymorphism in the CYP2E1 gen promoter affects skatole content in backfat of boars of two commercial Duroc-sired crossbred populations. Meat Sci. 92: 739-744. https://doi.org/10.1016/j. meatsci.2012.06.031

Munyaneza, J. P., A. Gunawan, \& R. R. Noor. 2019. Exploring effects of betaine-homocysteine methyltransferase(BHMT) gene polymorphisms on fatty acid traits and cholesterol in sheep. JITAA. 44: 243-251. https://doi.org/10.14710/ jitaa.44.3.243-251

Nei, M. \& S. Kumar. 2000. Moleculear Evolution and Phylogenetics. Oxford University. New York.

Neuhoff, C., A. Gunawan, M. O. Faroog, M. U. Cinar, C. G. Brinkhaus, S. Sahadevan, L. Frieden, D. Tesfaye, E.
Tholen, C. Looft, K. Schellander, \& M. J. Uddin. 2015 Preliminary study of FMO1, FMO5, CYP21, ESR1, PLIN2, and SULT2A1 as candidate gene for compounds related to boar taint. Meat Sci. 108: 67-73. https://doi.org/10.1016/j. meatsci.2015.05.025

Ooi, E. M. M., G. F. Watts, T. W. K. Ng, P. Hugh, \& R. Barrett. 2015. Effect of dietary fatty acids on human lipoprotein metabolism: A comprehensive update. Nutrients. 7: 44164425. https://doi.org/10.3390/nu7064416

Rasmussen, M. K., G. Zamaratskaia, \& B. Ekstrand. 2011. Gender-related differences in cytochrome P450 in porcine liver-implication for activity, expression and inhibition by testicular steroids. Reprod Domes Anim. 46: 616-623. https://doi.org/10.1111/j.1439-0531.2010.1714.x

Robic, A., C. Larzul, \& M. Bonneau. 2008. Genetic and metabolic aspects of androstenone and skatole deposition in pig adipose tissue: A review. GSE. 40: 129-143. https://doi. org/10.1051/gse:2007040

Santos, T. C., R. S. Gates, C. F. Souza, I. F. F. Tinoco, M. G. L. Candido, \& L. C. S. R. Freitas. 2019. Meat quality parameters and the effects of stress: a review. JAST-B. 9: 305-315. https://doi.org/10.17265/2161-6264/2019.05.001

Shija, D. S., L. A. Mtenga, A. E. Kimambo, G. H. Laswai, D. E. Mushi, D. M. Mgheni, A. J. Mwilawa, E. J. M. Shirima, \& J. G. Safari. 2013. Chemical composition and meat quality attributes of Indigenous sheep and goats from Traditional production system in Tanzania. Asian-Aust. J. Anim. Sci. 26-295-302. https://doi.org/10.5713/ajas.2012.12432

Silver, N., S. Best, J. Jiang, \& S. L. Thein. 2006. Selection of housekeeping genes for gene expression studies in human reticulocytes using real-time PCR. BMC Mol Biol. 7: 33. https://doi.org/10.1186/1471-2199-7-33

Stupin, A., L. Rasic, A. Matic, M. Stupin, Z. Kralik, G. Kralik, M. Grcevic, \& I. Drenjancevic. 2018. Omega-3 polyunsaturated fatty acids-enriched hen eggs consumption enhances microvascular reactivity in young healthy individuals. Appl. Physiol. Nutr. Metab. 43: 988-995. https://doi. org/10.1139/apnm-2017-0735

Weir, N., W. Guan, B. Steffen, L. M. Steffen, A. B. Karger, \& M. Y. Tsai. 2018. Omega-6 eicosadienoic Acid is associated with lower HOMA-IR and incident T2D in participants from the MESA cohort. Diabetes 67: 1560-P. https://doi. org/10.2337/db18-1560-P

Wiercinska, P., Y. Lou, \& E. J. Squires. 2012. The roles of different porcine cytochrome P450 enzymes and cytochrome b5A in skatole metabolism. Animals 6: 834-845. https://doi. org/10.1017/S1751731111002175

Zadinova, K., R. Stupka, A. Stratil, J. Cítek, K. Vehovsky, \& D. Urbanova. 2016. Boar taint - The effect of selected candidate genes associated with androstenone and skatole levels - A review. Anim. Sci. Pap. Rep. 34: 107-128.

Zadinova, K., R. Stupka, A. Stratil, J. Citek, K. Vehovsky, N. Lebedova, M. Sprysl, \& M. Okrouhla. 2017. Association analysis of SNPs in the porcine CYP2E1 gen with skatole, indole, and androstenone levels in back fat of a crossbred pig population. Meat Sci. 131: 68-73. https://doi org/10.1016/j.meatsci.2017.04.236

Zimerman, M., G. Grigioni, H. Taddeo, \& E. Domingo. 2011. Physiological stress responses and meat quality traits of kids subjected to different pre-slaughter stressors. Small. Rum. Res. 100: 137-142. https://doi.org/10.1016/j. smallrumres.2011.06.011 